\title{
A Comparative Study Between A Traditionally Taught Criminology Course And A Computer Hybrid Course: Does Technology In The Classroom Make A Difference?
}

Daniel Gutierrez, (E-mail: DGutierrez@valenciacc.edu), Valencia Community College

\begin{abstract}
Hybrid courses are the latest trend in the academic community. Little research however exists on this new delivery method. This study compares the performance of students $(n=36)$ enrolled in two criminology courses taught at a community college. One course was delivered using traditional lecture methods while the other course was delivered as a hybrid course. Using t-tests, seven variables were examined to determine statistical significance between the two groups of students. Performance measures included course requirements and final course grades for both classes. Course requirements were identical for each group. Hybrid students performed at higher levels than traditional students and t-test scores indicate statistically significant differences for exams and final scores between the two groups.
\end{abstract}

\subsection{Brief History of Distance Learning}

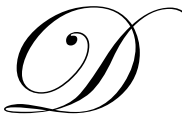

istance learning has a history that extends back to the nineteenth century where print was the major form of delivering distance education courses (Moore and Kearsley, 1996). Historically, it has been utilized to deliver instruction to adult learners living in remote areas where access to traditional education was almost nonexistent (Hawkins, 1999). Today, with the advent of more sophisticated technology such as the Internet, distance learning has become commonplace at all levels of education (Ahern and Repman, 1994; Dunn, 2000; Ascough, 2002; Harvey, 2002) and is expanding at an extremely rapid rate (Sherry, 1996). Latest figures from the U.S. Department of Education, for example, indicate that approximately three million students were enrolled in distance learning courses throughout the 2001-02 academic year in two-and four-year colleges (National Center for Education Statistics, 2003). This accounts for an increase of almost four times the number of students that were enrolled in distance courses during the 1994-95 academic year (NCES, 1997).

Traditionally, distance education was defined as the delivery of instructional materials to geographically dispersed individuals (Office of Technology Assessment, 1989), which occurred in a variety of ways including mail, telephone, faxes, and video tapes (Milheim, 2001). Today, the type of technology used to deliver distance education programs include two-way video and audio, one-way video, television broadcast, and use of the Internet using both synchronous and asynchronous methods just to name a few (National Center for Education Statistics, 2003). According to the NCES (2003) the most often used form of delivery was the Internet and video modes of delivery with 90 percent of the institutions surveyed indicating they used the Internet as the primary mode of instructional delivery.

\subsection{Review of the Literature}

Educational literature is replete with studies that compare distance learning classes with traditional classes (Martin and Rainey, 1993; Neushauser, 2002; Souder, 1993; Veruin and Clark, 1991). Beare (1989), McCleary and Egan (1989) and Sonner (1999) all indicate that with few exceptions, students enrolled in distance learning courses have similar experiences to students enrolled in traditional face-to-face courses in terms of learning outcomes. 
Souder (1993) for example, compared three different graduate level programs and found little differences in student outcomes. Other findings, however, indicate that students achieved higher course grades in distance learning courses than students enrolled in traditional courses (Bartlett, 1997; Bothun, 1998; Heines and Hulse, 1996; Kabat and Friedel, 1990; Schutte, 1996).

Because the concept of hybrid courses is relatively new (Young, 2002), only a paucity of research exists in this area. In fact, a review of the literature discovered less than a dozen articles that discussed the concept, design and assessment of hybrid models. While more institutions may be offering hybrid courses, the majority of research concerning the effectiveness of distance learning classes involves those classes that are entirely online or courses that consist of the "older generation" type of distance learning courses.

According to Lago (2000) the University of Central Florida is conducting the most extensive work in the area of hybrid courses. This includes developing, teaching, and assessing hybrid courses (Lago, 2000). The University of Central Florida's Research Initiative for Teaching Effectiveness (RITE) evaluation of hybrid courses indicates that hybrid course students have higher success and lower withdrawal rates than both traditional face-toface courses and courses that are taught completely online (http://pegasus.cc.ucf.edu/ rite/ImpactEvaluation.html). This data is limited because it only provides a descriptive analysis of the findings.

Student opinion in a research study by Leh (2002) on hybrid courses indicates that they favor hybrid models over traditional course models, feel they learned more in a hybrid setting and wished more hybrid courses could be offered by their institution. Leh's study is severally limited by the simple fact that most of the subjects compared in the study were teachers, a far cry from the traditional student. In fact, Leh emphatically states that, "these students were different from the students I had taught previously" (p. 32).

Finally, a recent study by Rivera and Rice (2002) compared student performance and satisfaction as well as instructor experiences between students enrolled in a traditional, hybrid and completely online course. Their findings indicate that while student satisfaction with the hybrid course may have been slightly higher, there were no differences in student performances. The study conducted by Rivera and Rice (2002) is flawed because outcome measures (exams) used were not identical for each delivery format. Identical exams and assignments were only given to the hybrid course and the course that was delivered completely online. The traditional course used different outcome measures than the other two courses invalidating any comparisons between the traditionally formatted course and the others.

\subsection{Hybrid Course Designs}

Before the development of hybrid courses, colleges and universities primarily developed contemporary distance courses as fully online courses that required no face-to-face interaction between faculty and students. These classes were virtual classes that allowed students access to course materials and the instructors solely through electronic means. Hybrid courses on the other hand, are designed using the conveniences of complete online courses without the total loss of face-to-face interaction among students and faculty (Garnham and Kaleta, 2002; Young, 2002). Hybrid courses are designed with several goals in mind. First, students get the best of both worlds. That is, they enjoy the benefits of having computer technology in the classroom and also having face-to-face interaction with the instructor. Second, class seat time is reduced by as much as fifty percent as classes generally meet every other class period. Third, both students and faculty commute time is reduced, as well as any problems compounded by commuting such parking, tolls and driving in inclement weather. And finally, hybrid courses tend to be more learning centered because they take into account different learning styles and use a wide variety of teaching methodologies to deliver the course content (Garnham and Kaleta, 2002; Young, 2002).

Three descriptions that best sum up hybrid courses are as follows: First, Arizona State University, (http://asuonline.asu.edu/FacultySupport/Hybrid.cfm\#overview) second; the description provided by the Learning Technology Center located at the University of Wisconsin-Milwaukee (http://www.uwsa.edu/ ttt/articles/garnham.htm) currently conducting the "Hybrid Project", and third; a brief description provided by the University of Central Florida (http://pegasus.cc.ucf.edu/ rite/ImpactEvaluation.html). 


\subsection{The Research Focus/Methodology}

This project focused on the following research question. Does the performance of students enrolled in a traditionally taught course differ from that of students enrolled in a computer hybrid class? The hypothesis explored is that there is no difference between students' performances for those enrolled in a traditional taught criminology course versus those enrolled in a course taught as computer hybrid course.

Using students from two criminology courses, student performance is compared for those enrolled in a criminology course in which the course content is delivered via traditional methods. The primary method of delivery in the traditional course involved lectures using conventional materials such as blackboards and overhead transparencies. Computers were not used to deliver any of the material in the traditional course. The hybrid course was specifically designed so that lectures, assignments and discussions included both face-to-face interaction and use of computers in and out of the classroom. The hybrid course class meetings were also conducted in a lab setting that allowed each student access to a computer station during lectures. Through the use of computers, students in the hybrid were able to access course materials such as lectures, course Web sites, study guides and student/instructors communications.

The traditional course was offered on the East Campus during the Spring Semester of 2002 and was offered during evening hours, while the hybrid course was offered on the West Campus during the Summer Semester of 2002 during regular daytime hours. A total of twenty-one students completed the traditional course while fifteen completed the hybrid course. Only students that completed the course are compared in this analysis.

Students in both courses were required to complete the following five course requirements.

- $\quad$ Three regular course exams from selected chapters

- $\quad$ One theoretical case study (theoretical application exercise)

- $\quad$ One comprehensive final exam

Students were also given study guides to help them prepare for exams but completion of them was not a requirement. All course requirements were identical. The course textbook was identical as were the chapters selected from the text. Study guides that students received were also identical. Theoretical case study requirements were identical and consisted of both classes touring a maximum-security prison concluding with a one-hour panel interview of three inmates delving into their family, social and criminal histories.

In order to ensure that substantial academic differences did not exist between the two groups prior to enrolling in the course, school records were electronically accessed and students' grade point averages were recorded and a statistical analysis was performed to determine if any significant differences existed between the two groups. T-tests were used to determine statistical differences. Once students completed their particular course requirements, t-tests were performed on each course requirement to determine if any statistical difference existed in student performances between the two groups. Final course grades were also included in the analysis.

\subsection{Findings}

The mean grade point average for students prior to enrolling in the traditional course was 2.74 (sd .689 and df 32) while the students enrolled in the hybrid course had a slightly higher mean score of 2.87 (sd .552). T-tests indicate no statistical significance in this area between the two groups.

Comparing the six course outcomes, however, yielded quite different results. As indicated in table 1 students enrolled in the hybrid course had higher mean scores than the traditional group in five of the six course outcomes. Three of the outcomes, exam 1, exam 2 and final course grades produced results that were statistically significant at the alpha .05 level (see table 1). 
Table 1. Performance Measures For Students Enrolled In Traditional And Hybrid Criminology Course

$\underline{\text { Traditional Students }}$

Hybrid Students

\begin{tabular}{|lcccccc|}
\hline $\begin{array}{l}\text { Performance } \\
\text { Measures }\end{array}$ & Mean Score & sd & df & Mean Score & sd & (p =) \\
\hline GPA & 2.74 & .689 & 32 & 2.87 & .552 & .558 \\
\hline Exam 1 & 76.4 & 13.79 & 33 & 90.0 & 8.9 & $.002^{*}$ \\
\hline Exam 2 & 77.7 & 10.5 & 32 & 85.2 & 8.74 & $.033^{*}$ \\
\hline Exam 3 & 77.4 & 10.6 & 32 & 76.5 & 13.9 & .610 \\
\hline Case Study & 84.6 & 12.4 & 34 & 87.1 & 9.6 & .556 \\
\hline Final Exam & 79.5 & 8.7 & 34 & 83.5 & 11.9 & .251 \\
\hline Final Grade & 80.8 & 6.5 & 34 & 87 & 8.8 & $.031^{*}$ \\
\hline
\end{tabular}

*Note: Denotes statistical significance at $\mathrm{p}<.05$ level.

Overall, final student performance in the two courses yielded the following results. Forty percent of the hybrid students completed the course with an A grade (90\% or higher) while only $9.5 \%$ of the traditional students achieved an A in the course. For the hybrid group, 40\% completed the course with a B (80-89\%) while 57\% of traditional students completed the course with a B. Those students completing the course in the $\mathrm{C}$ range (70-79\%) consisted of $20 \%$ of the hybrid class and $28.6 \%$ of the traditional class. Finally, $4.8 \%$ of traditional students earned a $\mathrm{D}$ in the course while the lowest score earned among hybrid students was a $\mathrm{C}$ (see figure 1).

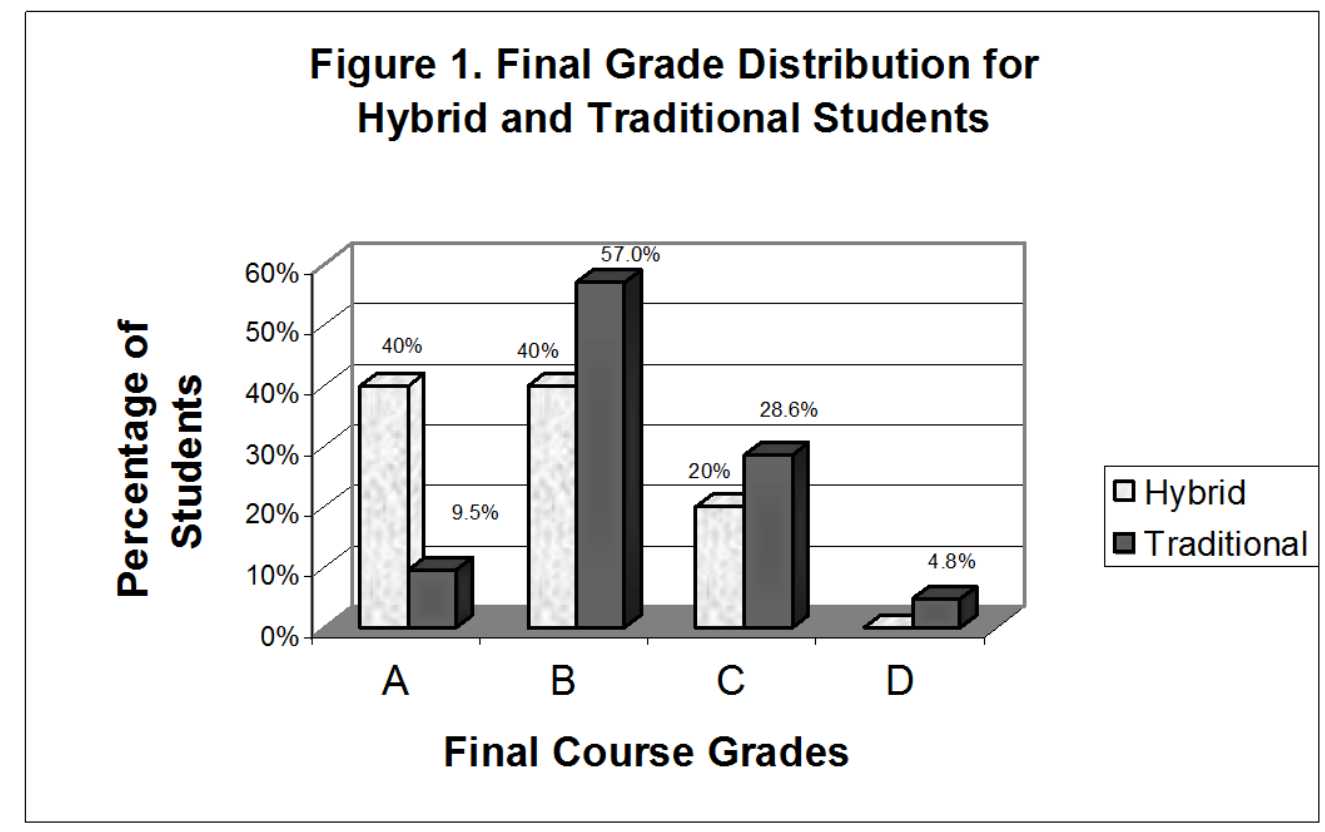

\subsection{Discussion}

Data indicate that students enrolled in the hybrid course outperformed the students in the traditional course by substantial margins. The hybrid students performed better in five of the six course outcomes. Three of the areas of performance were statistically significance including final grades in the course. Forty percent of the students in the hybrid course completed the course with an A while only 9.5 percent of the students enrolled in the traditional course achieved a final grade of A. While substantial differences may exist, caution must be used not to over generalize the findings to the general population. Several limitations to the study exist that should be noted and precaution should be exercised regarding the findings. First, the sample used is relatively small $(n=36)$. Second, 
student characteristics that may have impacted final course outcomes were not included. These include such variables as student maturity, previous college course experiences, levels of computer knowledge and skills, individual motivational factors that may have influenced students in both positive and negative ways. Finally other factors that may attributed to differences that were not considered include student learning styles, attendance and life distractions that may have occurred while students were enrolled in the courses.

While these limitations are nonetheless important and perhaps raise more questions than the research intended to answer, data indicates that hybrid students outperformed those enrolled in the traditionally taught course. The study is important because it actually measures outcome differences using inferential statistics rather than just descriptive statistics. As Ritchey (2000) has noted, descriptive statistics only provide for the number of observations that are recorded in specific categories yielding percentages, while inferential statistics allow us to measure causeand-effect relationships and to perform hypothesis testing (Ritchey, 2000). Additionally, it addresses this relatively new format in distance learning that is being implemented throughout colleges and universities across the country and contributes to the exigent amount of literature in the area and raises question for further research.

\subsection{Final Thoughts/Recommendations}

While it is clear that students in the hybrid class performed much better compared to those in the traditional class, several research questions remain to be answered. First and foremost is, "why did they perform better?" What variables could account for the differences in student performance? Does course design play an important role in this process? Is the availability of computers in the classroom a factor? And last but least, are there faculty attributes that need to be considered?

Addressing the last question, it must be noted that this is not the first time that I have developed and taught a course using this particular format. In fact, several solid design principles were used in the construction of the hybrid course. McKimm, Jollie and Cantillon (2003) for example, point out that one of the main barriers to teaching an effective distance learning course is the technology itself. This can create a host of problems that are compounded as the semester progresses if they are not handled immediately or not considered during the design of the course. Caverly and MacDonald (1999) have also noted that instructors should adhere to several good practice principles that include student-student interactions, student-faculty interactions, prompt feedback, developing supportive learning communities and utilizing active learning techniques.

\subsection{References}

1. Ahern, T. C., \& Repman, J. (1994). The Effects of Technology on Online Education. Journal of Research on Computing in Education, Vol. 26, 4, 537-546.

2. Arizona State University. ASUonline. Retrieved October 2, 2003 from http://asuonline.asu.edu/FacultySupport/Hybrid.cfm\#overview

3. Ascough, R. S. (2002). Designing for Online Distance Education: Putting Pedagogy Before Technology. Teaching Theology and Religion, Vol. 5, 1, 17-29.

4. Aycock, A., Garnham, C., \& Kaleta, R. (2002). Lessons Learned from the Hybrid Course Project. Learning Technology Center, University of Wisconsin-Milwaukee, Vol. 8, No. 6. Retrieved October 5, 2003 from http://www.uwsa.edu/ttt/articles/ garnham2.htm.

5. Bartlett, T. (1997). The Hottest Campus on the Internet. Business Week, 77-80.

6. Beare, P. L. (1989). The Comparative Effectiveness of Videotape, audiotape, and telecture. The American Journal of Distance Education, 3, 2, 57-66.

7. Bothun, G. D. (1998). Distance Education: Effective Learning or Content-free Credits? Cause/Effect, 21, 2, 28-37.

8. Caverly, D. C., and MacDonald, L. (1999). Techtalk: Asynchronous Distance Developmental Education. Journal of Developmental Education, Vol. 23, 2, 36-37.

9. Dunn, S. L. (2000). The Virtualizing of Education. The Futurist, 34, 2: 34-38. 
10. Garnham, C., \& Kaleta, R. (2002). Introduction to Hybrid Courses. Learning Technology Center, University of Wisconsin-Milwaukee, Vol. 8, No. 6. Retrieved October 10, 2003 from http://www.uwsa.edu/ttt/articles/garnham.htm.

11. Harvey, D. (2002). A New Technology-First Framework for the Future Design of Online Learning. The Quarterly Review of Distance Education, Vol. 3, 1, 59-63.

12. Hawkins, B. L. (1999). Distributed Learning and Institutional Restructuring. Educom Review, 34, 4, 12-15 \& 42-44.

13. Heines, R. A., and Hulse, D. B. (1996). Two-way Interactive Television. The American Journal of Distance Education, 3, 1, 50-60.

14. Kabat, E. J., and Friedel, J. (1990). The Development, Pilot-testing, and Dissemination of a Comprehensive Evaluation Model for Assessing the Effectiveness of a Two-way Interactive Distance Learning System. Davenport, Iowa: Eastern Iowa Community College. (ERIC Document Reproduction Service No. ED 332 690).

15. Lago, M. E. (November 2000). The Hybrid Experience: How Sweet It Is! Converge Magazine. Retrieved October 10, 2003 from http://www.convergemag.com/ Publications/CNVGNov00/hybrid/index.shtm

16. Leh, A. S. (2002). Action Research on Hybrid Courses and their Online Communities. International Council for Education Media, 31-38.

17. Martin, E. E., and Rainey, L. (1993). Student Achievement and Attitude in a Satellite-delivered High School Science Class. The American Journal of Distance Education, 7, 1, 54-61.

18. McCleary, I. D., and Egan, M. W. (1989). Program Design and Evaluation: Two-way Interactive Television. The American Journal of Distance Education, 3, 1, 50-60.

19. McKimm, J., Jollie, C., and Cantillon, P. (2003). Web-based Learning. British Medical Journal, Vol. 326.

20. Milheim, W. (2001). Faculty and Administrative Strategies for the Effective Implementation of Distance Education. British Journal of Educational Technology, Vol. 32, 5, 535-542.

21. Moore, M. G., \& Kearsley, G. (1996). Distance Education: A Systems View. Belmont, CA: Wadsworth Publishing Company.

22. Neuhauser, C. (2002). Learning Styles and Effectiveness of Online and Face-to-Face Instruction. The American Journal of Distance Education, 16, 2, 99-113.

23. Ritchey, F. (2000). The Statistical Imagination: Elementary Statistics for the Social Sciences. Boston, MA: McGraw-Hill.

24. Rivera, J. C., and Rice, M. L. (2002). A Comparison of Student Outcomes \& Satisfaction Between Traditional \& Wen Based Course Offerings. Online Journal of Distance Learning Administration, Vol. V, 3, Fall 2002. Retrieved October 5, 2003 from http://www.westga.edu/ distance/ojdla/fall53/rivera53.html

25. Schutte, J. G. (1996). Virtual Teaching in Higher Education: The New Intelectual Superhighway or Just Another Traffic Jam?

26. Sherry, L. (1996). Issues in Distance Learning. International Journal of Educational Telecommunications, $1,4,337-365$.

27. Souder, W. E. (1993). The Effectiveness of Traditional vs. Satellite Delivery in Three Management of Technology Master's Degree Programs. The American Journal of Distance Learning, 7, 1, 37-53.

28. University of Central Florida. Distributed Learning Impact Evaluation. Retrieved October 15, 2003 from http://pegasus.cc.ucf.edu/ rite/ImpactEvaluation.html

29. U.S. Congress, Office of Technology Assessment. (1988). Power on! New Tools for Teaching and Learning. OTA-Set-379. Washington, D.C.: U.S. Government Printing Office.

30. U.S. Department of Education (1997). National Center for Educational Statistics. Distance Education in Higher Learning Education Institutions, NCES 98-062. Retrieved October 10, 2003 from http://nces.ed.gov/surveys/peqis/publications/ 98062/

31. U.S. Department of Education (2003). National Center for Educational Statistics. Distance Education at Degree-Granting Postsecondary Institutions: 2000-2001. NCES 2003-017. Retrieved October 10, 2003 from http://nces.ed.gov/pubs2003/ 2003017.pdf

32. Veruin, J. R., and Clark, T. (1991). The Foundations of Effective Practice. San Francisco: Jossey-Bass.

33. Young, J. R. (22, March 2002). Hybrid Teaching Seeks to End the Divide Between Traditional and Online Instruction. Chronicle of Higher Education, Vol. 48, 28, A33-1c. Retrieved October 5, 2003 from http://chronicle.com/free/v48/i28/ 28a03301.html 